\title{
The Protective Role of Thiola against the Genotoxic Effect of Potassium Dichromate in Mice in vivo
}

\author{
Maha A. Fahmy ${ }^{1} *$, Soheir Abdel-Kawy ${ }^{2}$ and Entesar E. S. Hassan ${ }^{1}$ \\ ${ }^{1}$ Department of Genetics and Cytology, National Research Centre, Dokki, Cairo, Egypt \\ ${ }^{2}$ Faculty of Science-Al-Azhar University, Cairo, Egypt
}

Accepted November 13, 2000

\begin{abstract}
Summary The genotoxic effect of hexavalent potassium dichromate $\left(\mathrm{K}_{2} \mathrm{Cr}_{2} \mathrm{O}_{7}\right)$ was investigated in mice in vivo using sister chromatid exchange (SCE) and chromosomal aberration analysis. $\mathrm{K}_{2} \mathrm{Cr}_{2} \mathrm{O}_{7}$ induced a significant increase in the frequency of SCE's after intraperitoneal (i.p.) treatment with the doses $6,12,24 \mathrm{mg} \mathrm{kg}^{-1}$ b.wt. which correspond to $1 / 8,1 / 4$ and $1 / 2$ of the experimental $\mathrm{LD}_{50}$. The lowest tested dose $3 \mathrm{mg} \mathrm{kg}^{-1}$ b.wt. had no effect with respect to SCE's and its effect reached $6.57 \pm 0.36 /$ cell compared with $5.80 \pm 0.55 /$ cell for the control. The frequency of SCE's reached $9.03 \pm 0.20$ after treatment with the highest tested dose of $\mathrm{K}_{2} \mathrm{Cr}_{2} \mathrm{O}_{7}$, a value which is less than that induced by mitomycin $\mathrm{C}(13.10 \pm 0.40)$ as the positive control. Thiola at the concentrations of 20 and $50 \mathrm{mg} \mathrm{kg}^{-1}$ b.wt. had moderate but non-significant effect for minimizing the frequency of SCE's induced by different doses of $\mathrm{K}_{2} \mathrm{Cr}_{2} \mathrm{O}_{7}$.

With respect to chromosomal aberrations, all the tested concentrations of $\mathrm{K}_{2} \mathrm{Cr}_{2} \mathrm{O}_{7}(3,6,12$, $24 \mathrm{mg} \mathrm{kg}^{-1}$ b.wt.) induced a significant increase in the percentage of chromosomal aberrations in mouse bone marrow as well as in mouse spermatocytes $24 \mathrm{~h}$ after single i.p. treatment. The incidence of chromosomal damage increased significantly with increasing the dose. However mitomycin $\mathrm{C}$ induced higher effect. The results also show that the pretreatment with thiola at the dose of $50 \mathrm{mg} \mathrm{kg}^{-1}$ b.wt. significantly reduced the percentage of chromosomal aberrations induced by $\mathrm{K}_{2} \mathrm{Cr}_{2} \mathrm{O}_{7}$ in all the treatment groups and the results confirm the protective role of thiola which has been proved previously against the genotoxicity of some mutagens.
\end{abstract}

The contamination of our environment with metal compounds has expanded to include the general public health. Metal mutagenesis has only been little studied, although many of them are reported to be carcinogenic (IARC 1990, Singh et al. 1999, Carlisle et al. 2000).

Mutagenesis by chromium is of potential interest in view of human exposure to this metal. The main uses of chromium salts are metallurgical, refractory and chemical industries. The high coloured salts of chromium are used as pigments and as mordants in textile industry, in tanning, in photographic emulsions, as catalysts for organic and inorganic reactions and in ceramics. Chromium is also used in explosives (Leonard and Lauwerys 1980).

The actual health problems due to chromium salts seems to be restricted to hexavalent chromium $\mathrm{Cr}^{6+}$. This is probably because hexavalent form can cross cell membrane easily via sulfate transport system and be reduced intracellularly to trivalent chromium which is the ultimate toxic agent capable of binding to cellular components (Biedermann and Landolph 1990). $\mathrm{Cr}^{6+}$ compounds induce point mutation in bacteria (Bianchi et al. 1983), and yeasts (Bonatti et al. 1976), morphological infidelity of DNA replication in vitro (Bianchi et al. 1983), morphological transformation in hamster embryonic cells (Tsuda and Kato 1977) and chromosomal aberrations in cultured human lymphocytes in vitro (Alain et al. 1997). However there are few reports concerned with its mammalian in vivo mutagenicity (Knudsen 1980, Itoh and Shimada 1998).

Among $\mathrm{Cr}^{6+}$ compounds, potassium dichromate $\left(\mathrm{K}_{2} \mathrm{Cr}_{2} \mathrm{O}_{7}\right)$ is strong cytotoxic agent in mam- 
malian cell cultures, differentially inhibiting nucleic acid and protein synthesis and affecting the uptake of nucleosides and amino acids through the plasma membrane (Levis et al. 1978a, b). $\mathrm{K}_{2} \mathrm{Cr}_{2} \mathrm{O}_{7}$ also interferes with the mitotic process, giving rise to different kinds of mitotic blockage and caryological alterations (Majone 1977).

In the present article we describe the induction of sister chromatid exchanges (SCE's) and chromosomal aberrations in both somatic and germ cells of male mice in vivo after single i.p. treatment with different concentrations of $\mathrm{K}_{2} \mathrm{Cr}_{2} \mathrm{O}_{7}$. The protective effect of 2-mercaptopropionylglycine (thiola) was also studied. Thiola is a sulfhydryl compound widely used as detoxicating agent and also has a variety of pharmacological activities (Ezzat et al. 1982). Thiola was found to possess significant reduction in the frequency of chromosomal aberrations induced by radiation (Uma Devi and Prasanna 1990) and some chemical mutagens (Galdean et al. 1986, Schunck et al. 1998). Therefore, the protective role of thiola was studied in a trial to minimize the genotoxicity of $\mathrm{K}_{2} \mathrm{Cr}_{2} \mathrm{O}_{7}$.

\section{Materials and methods}

\section{Animals}

Mature male white Swiss mice aged 9-12 weeks and weighing 25-30 g were used in all experiments. The tested animals were obtained from a closed random-bred colony at the National Research Centre, maintained under controlled conditions of temperature and humidity and receiving food and water ad libitum.

\section{Chemicals}

Potassium dichromate (99.5\%) was purchased from S.D. FINE. CHEM. Ltd. Egypt.

Thiola: N-(2-mercaptopropionylglycine) was purchased from Sigma Chemical Co., St. Lewis, Mo. U.S.A.

\section{Treatment and cytological preparations}

Sister chromatid exchange: Four doses of $\mathrm{K}_{2} \mathrm{Cr}_{2} \mathrm{O}_{7}$ (dissolved in distilled water) were tested i.p. for the induction of SCE's in mouse bone-marrow cells. The doses were $3,6,12,24 \mathrm{mg} \mathrm{kg}^{-1}$ b.wt. which correspond to $1 / 16,1 / 8,1 / 4,1 / 2 \mathrm{LD}_{50}$. The $\mathrm{LD}_{50}$ of $\mathrm{K}_{2} \mathrm{Cr}_{2} \mathrm{O}_{7}$ was determined experimentally. The experimental procedure was conducted according to Madrigal-Bujaidar et al. (1998). A subcutaneous implantation of 5-bromodeoxyuridine (BrdU, Sigma) tablet weighing $55 \pm 5 \mathrm{mg}$ was initially made in each mouse and $30 \mathrm{~min}$ later the test compound was administered by an i.p. injection. After $21 \mathrm{~h}$ the animals received an i.p. injection of colchicine $\left(0.6 \mathrm{mg} \mathrm{kg}^{-1} \mathrm{~b}\right.$.wt. $)$ and $2 \mathrm{~h}$ later, the bone-marrow of both femus were obtained in $\mathrm{KCL} 0.075 \mathrm{M}$ at $37^{\circ} \mathrm{C}$ keeping the cells $20 \mathrm{~min}$ at the same temperature, then the fixation process with methanol-acetic acid $(3: 1)$ was done changing the solution at least twice. Metaphase spreads were air-drying prepared. Chromatid differentiation was achieved with the fluorescence plus Giemsa method of Goto et al. (1978) with the use of black lights. About 40 metaphase spreads per animal were examined microscopically for SCE's.

The protective effect of thiola was screened by using 2 concentrations of thiola 20 and $50 \mathrm{mg} \mathrm{kg}^{-1}$ b.wt. which are far below its toxic dose $(2100 \mathrm{mg} / \mathrm{kg})$ as reported by Sugahara and Srivastava (1976). Each concentration was tested in 3 groups of mice given $\mathrm{K}_{2} \mathrm{Cr}_{2} \mathrm{O}_{7}$ at concentrations of $6,12,24 \mathrm{mg} \mathrm{kg}^{-1}$ b.wt. Thiola was injected i.p. $2 \mathrm{~h}$ prior to the administration of $\mathrm{K}_{2} \mathrm{Cr}_{2} \mathrm{O}_{7}$.

Chromosomal aberration: For bone marrow or spermatocytes, groups of 5 animals were injected i.p. with a single dose of $\mathrm{K}_{2} \mathrm{Cr}_{2} \mathrm{O}_{7}$ at the doses of $3,6,12,24 \mathrm{mg} \mathrm{kg}^{-1}$ b.wt. Mice were killed $24 \mathrm{~h}$ post treatment. Another groups of mice were i.p. injected with thiola $50 \mathrm{mg} \mathrm{kg}^{-1} \mathrm{~b}$.wt. $2 \mathrm{~h}$ prior to the administration of $\mathrm{K}_{2} \mathrm{Cr}_{2} \mathrm{O}_{7}$ at the doses of $6,12,24 \mathrm{mg} \mathrm{kg}^{-1}$ b.wt. For bone-marrow and spermatocyte metaphase preparations, air-dried techniques were made according to Yosida and Amano (1965) and Evans et al. (1964) respectively. Slides were stained with phosphate-buffered Giemsa 
7\%. At least 75-100 well spread metaphases were analyzed per each animal scoring different types of chromosomal aberrations.

For all the above experiments, a control group of non-treated mice was run alongside the test material in addition to the positive control group treated i.p. with $1 \mathrm{mg} \mathrm{kg}^{-1}$ b.wt. mitomycin C.

\section{Statistical analysis}

In all experiments the resulting data were compared statistically using Fisher's least significant differences and Duncan's multiple range test. The significance of the incidence of abnormalities in experimental versus control data was calculated using the $t$-test.

\section{Results and discussion}

The ability of $\mathrm{K}_{2} \mathrm{Cr}_{2} \mathrm{O}_{7}$ to induce SCE's in mice bone marrow cells was investigated i.p. at different dose levels 3, 6, 12, $24 \mathrm{mg} \mathrm{kg}^{-1}$ b.wt. (Table 1, Fig. 1a-c). The doses 6, 12, $24 \mathrm{mg} \mathrm{kg}^{-1} \mathrm{~b} . \mathrm{wt}_{\text {. }}$ induced a significant increase in the frequency of SCE's over that of the control with a dose-related relationship. Such frequency of SCE's reached $7.90 \pm 0.33,8.40 \pm 0.25,9.03 \pm 0.20$ per cell after treatment with the 3 doses respectively compared with $5.80 \pm 0.55$ per cell for the control.

The frequency of SCE's induced after treatment with $\mathrm{K}_{2} \mathrm{Cr}_{2} \mathrm{O}_{7}$ was lower than that induced by mitomycin C (13.10 \pm 0.40 /cell) which is well known to be strong SCE's inducing agent (Russo et al. 1993) and was included as a positive control. The results in the present work are in agreement with the previous findings of Majone and Levis (1979) and Bianchi et al. (1983) who reported that $\mathrm{K}_{2} \mathrm{Cr}_{2} \mathrm{O}_{7}$ induced a dose related increase in the frequency of SCE's in Chinese hamster cells (CHO) and in other mammalian cell systems in vitro. The same authors reported that mitomycin $\mathrm{C}$ induced higher effect. A linear increase in the frequency of SCE's was also reported by Ohno et al. (1982) concerning the effect of chromium compounds in Don Chinese hamster cells.

Thiola is one of the most potentially active radioprotector and is widely used as detoxicating agent (Ezzat et al. 1982). Thiola was successfully reduced the frequencies of SCE's induced by neocarzinostatin in Chinese hamster ovary (CHO) cell (Schunck et al. 1998). In the present work 2 different doses of thiola 20 and $50 \mathrm{mg} \mathrm{kg}^{-1}$ b.wt. were tested i.p. to minimize the effect of $\mathrm{K}_{2} \mathrm{Cr}_{2} \mathrm{O}_{7}$ on SCE's. The results show that thiola did not induce SCE's of its own at the tested concentrations and its effect was statistically non significant compared with the control. The administration of thiola $2 \mathrm{~h}$ prior to $\mathrm{K}_{2} \mathrm{Cr}_{2} \mathrm{O}_{7}$ moderately minimized the induced $\mathrm{K}_{2} \mathrm{Cr}_{2} \mathrm{O}_{7}$ SCE's with statistical non-significant result as compared with that groups treated with $\mathrm{K}_{2} \mathrm{Cr}_{2} \mathrm{O}_{7}$ alone (Table 1).

Single i.p. treatment with $\mathrm{K}_{2} \mathrm{Cr}_{2} \mathrm{O}_{7}$ at the doses of $3,6,12,24 \mathrm{mg} \mathrm{kg}^{-1}$ b.wt. induced also significant percentage of chromosomal aberrations in mouse bone-marrow cells (Table 2, Fig. 1d-f). Such increase was found to be dose-dependent. It reached $14.67 \pm 0.40$ after treatment with the highest tested dose compared with $4.80 \pm 0.33$ for the control. The value is less than that induced after i.p. treatment with mitomycin $\mathrm{C}(28.30 \pm 0.26)$ as the positive control. The main types of aberrations observed were gaps, isochromatid breaks, fragments and deletions. Few cells with translocations were observed. Numerical chromosomal aberrations in the form of endomitosis (C-mitosis) were observed in all treated groups suggesting an effect on the mitotic spindle (Benjamin and Stephen 1996). These results are outlined with the previous data in cultured mammalian cells which showed that $\mathrm{K}_{2} \mathrm{Cr}_{2} \mathrm{O}_{7}$ behaves as a powerful clastogenic agent, producing a significant increase in chromosomal aberrations including gaps, breaks and exchanges when added to hamster embryonic cells (Tsuda and Kato 1976, 1977), to a cultured Chinese hamster cell line (Newbold et al. 1979), to $\mathrm{FM}_{3} \mathrm{~A}$ cells from a $\mathrm{C}_{3} \mathrm{H}$ mouse carcinoma (Umeda and Nishimura 1979) to human lymphocyte cultures (Nakamuro et al. 1978). Majone (1977) reports that this compound induces mitotic inhibition as well as perturbation in mitotic spindles in human cells (HEP line).

Moreover $\mathrm{K}_{2} \mathrm{Cr}_{2} \mathrm{O}_{7}$ showed similar dose effect relationship in micronucleus assay using the 
Table 1. Frequency of sister chromatid exchanges (SCE's) in mouse bone-marrow cells after i.p. treatment with potassium dichromate and thiola

\begin{tabular}{|c|c|c|c|c|c|}
\hline & Treatment and doses & No. of mice & $\begin{array}{l}\text { No. of examined } \\
\text { metaphases with }\end{array}$ & SCE's No. & $\begin{array}{l}\text { SCE's/Cell } \\
\text { Mean+SEF }\end{array}$ \\
\hline \multirow{6}{*}{$\begin{array}{l}\text { I. } \\
\text { II. }\end{array}$} & Control (non-treated) & 5 & 200 & 1160 & $5.80 \pm 0.55$ \\
\hline & Potassium dichromate ( $\mathrm{mg} \mathrm{kg}^{-1}$ b.wt.) & & & & \\
\hline & 3 & 5 & 200 & 1314 & $6.57 \pm 0.36$ \\
\hline & 6 & 5 & 200 & 1580 & $7.90 \pm 0.33^{*}$ \\
\hline & 12 & 5 & 200 & 1680 & $8.40 \pm 0.25 * *$ \\
\hline & 24 & 5 & 200 & 1806 & $9.03 \pm 0.20 * *$ \\
\hline III. & Thiola (50 $\mathrm{mg} \mathrm{kg}^{-1}$ b.wt.) & 5 & 200 & 1220 & $6.10 \pm 0.13$ \\
\hline \multirow[t]{4}{*}{ IV. } & $\begin{array}{r}\text { Potassium dichromate }\left(\mathrm{mg} \mathrm{kg}^{-1} \text { b.wt.) }\right. \\
\text { +Thiola ( } 50 \mathrm{mg} \mathrm{kg}^{-1} \text { b.wt.) }\end{array}$ & & & & \\
\hline & $6 \quad+$ Thiola & 5 & 200 & 1500 & $7.50 \pm 0.22 *$ \\
\hline & + Thiola & 5 & 200 & 1536 & $7.68 \pm 0.27 *$ \\
\hline & $24 \quad+$ Thiola & 5 & 200 & 1676 & $8.38 \pm 0.38 * *$ \\
\hline $\mathrm{V}$. & Thiola $20 \mathrm{mg} \mathrm{kg}^{-1}$ b.wt. & 5 & 200 & 1200 & $6.00 \pm 0.28$ \\
\hline \multirow[t]{4}{*}{ VI. } & $\begin{array}{r}\text { Potassium dichromate }\left(\mathrm{mg} \mathrm{kg}^{-1} \text { b.wt. }\right) \\
+ \text { Thiola }\left(20 \mathrm{mg} \mathrm{kg}^{-1} \text { b.wt.) }\right.\end{array}$ & & & & \\
\hline & $6 \quad+$ Thiola & 5 & 200 & 1396 & $6.98 \pm 0.20 *$ \\
\hline & +Thiola & 5 & 200 & 1520 & $7.60 \pm 0.60 *$ \\
\hline & $24 \quad+$ Thiola & 5 & 200 & 1630 & $8.15 \pm 0.14 * *$ \\
\hline VII. & $\begin{array}{l}\text { Mitomycin C } \\
\text { (Positive control) } 1 \mathrm{mg} \mathrm{kg}^{-1} \text { b.wt. }\end{array}$ & 5 & 200 & 2620 & $13.10 \pm 0.40^{* * *}$ \\
\hline
\end{tabular}

* Significant at 0.05 level, $* *$ Significant at 0.01 level, $* * *$ Significant at 0.001 level $(t$-test $)$

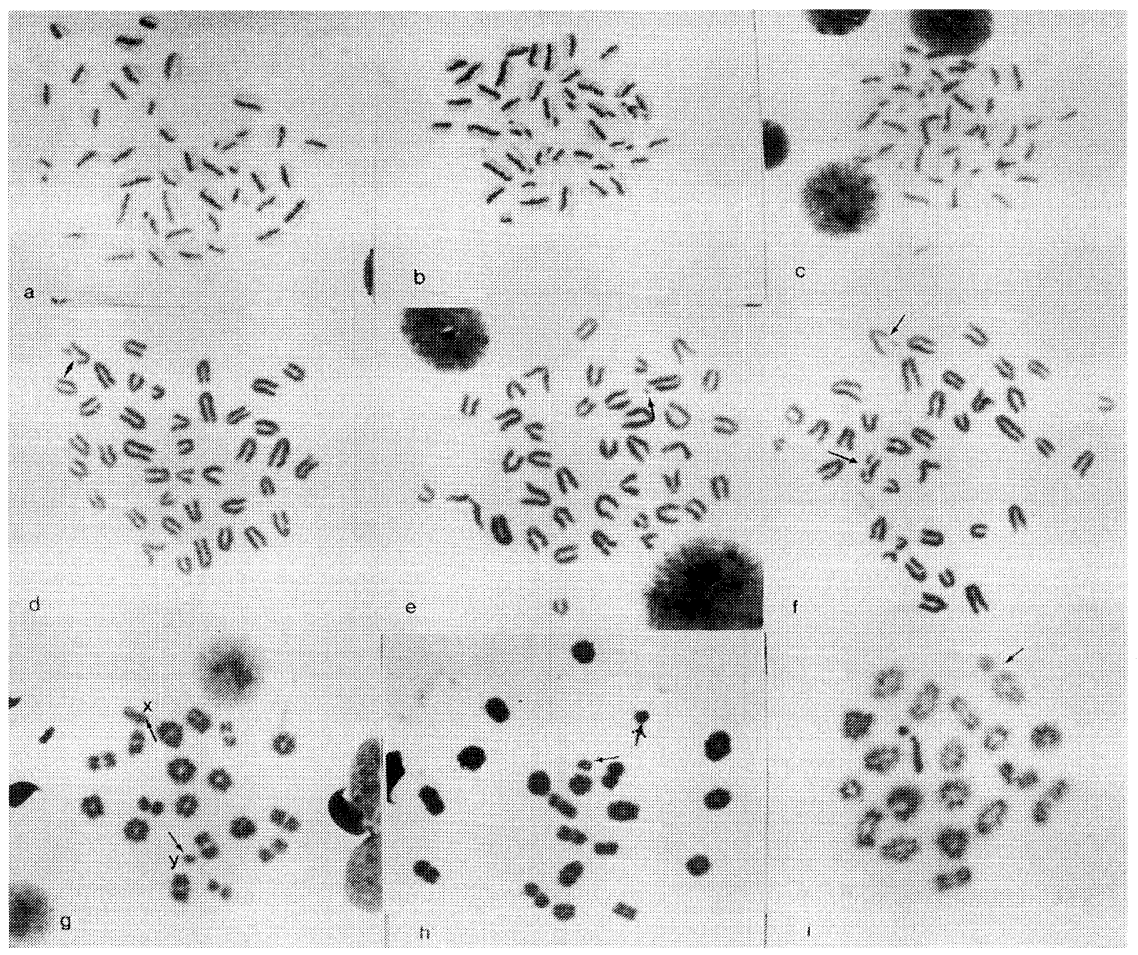

Fig. 1. Metaphases from mouse bone-marrow showing. a-c) SCE's induced after treatment with different doses of $\mathrm{K}_{2} \mathrm{Cr}_{2} \mathrm{O}_{7}$, d) chromatid break, e) fragment, f) gap and break. Metaphases from mouse spermatocytes treated with $\mathrm{K}_{2} \mathrm{Cr}_{2} \mathrm{O}_{7}$ showing. g) X-Y univalent, h) autosomal univalent, i) break. 


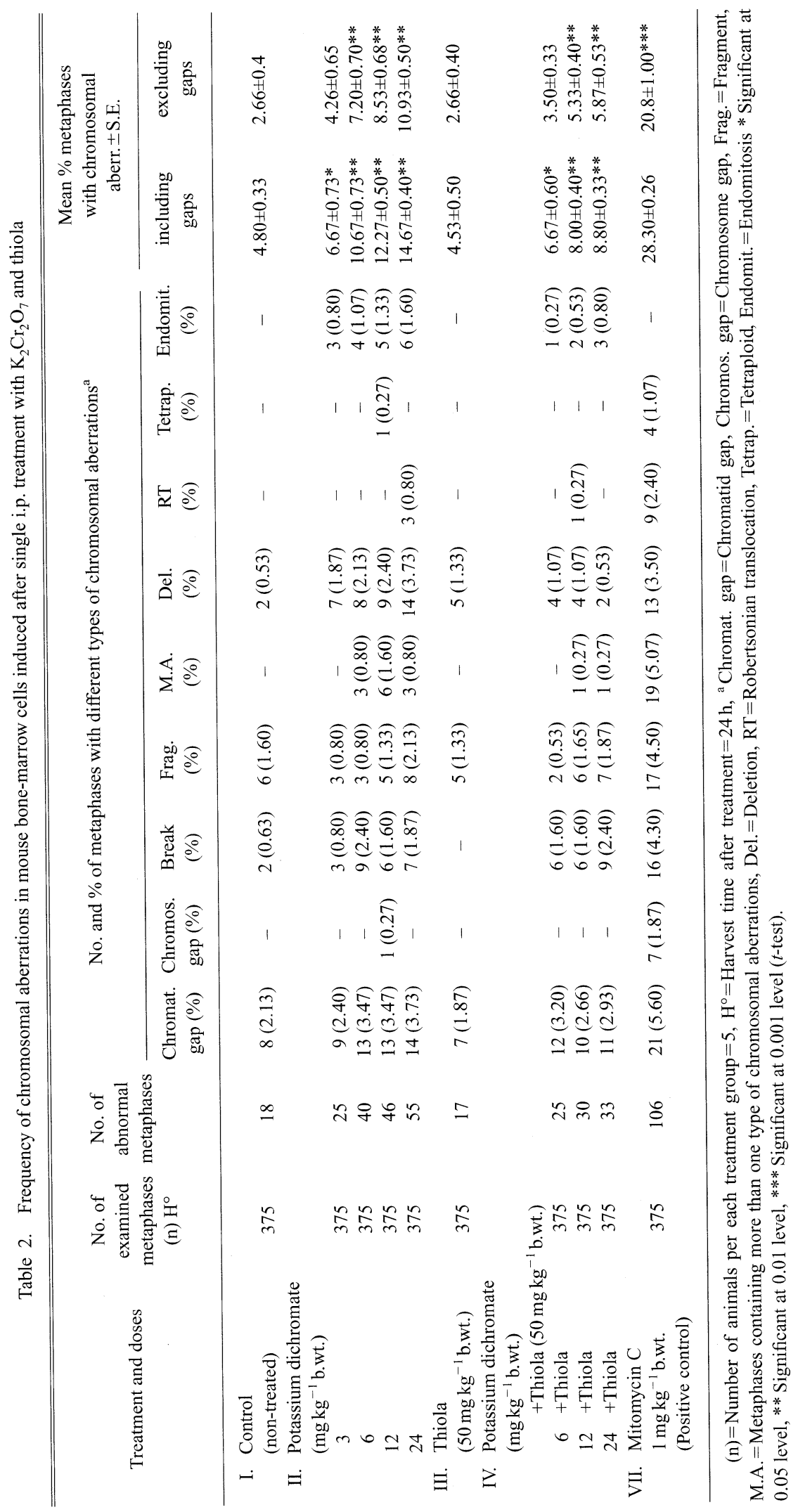




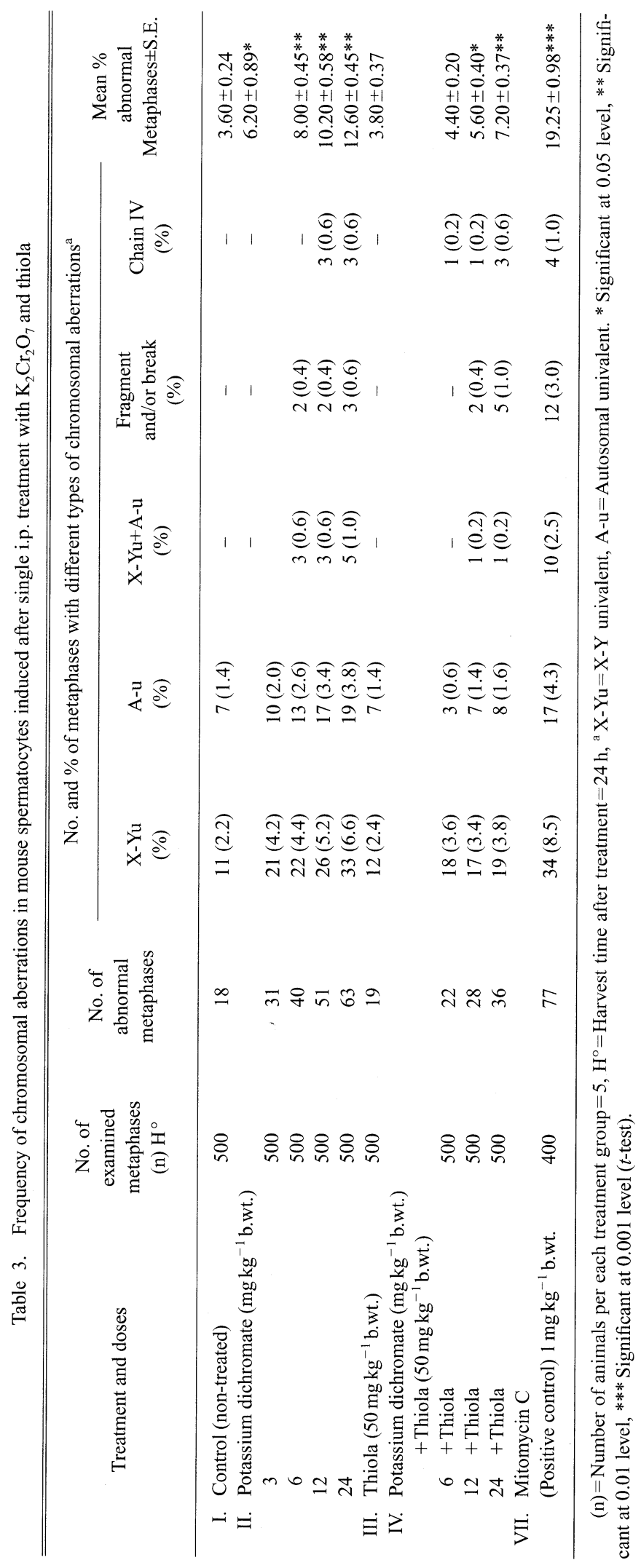


permanent fish cell line RTG-2 in vitro (Kohlpoth et al. 1999) and also in plant cells (Siegfried et al. 1998).

Changes in $\mathrm{Ca}^{2+}$ concentration can influence the induction of chromosomal aberrations induced by chromium compounds (Anghileri 1973), an effect probably related to the fact that calcium contributes to maintain the integrity of chromosome structure (Mazia 1954). Chromium has multiple effects in cells which may produce mutations in DNA (Casadevall et al. 1999). Chromium is known to increase the concentration of hydroxyl radicals in cells via the Fenton reaction path way, and these radicals may react with DNA causing both base damage and strand breaks (Aiyar et al. 1989, Strohs and Bagchi 1995). Additionally, it has been shown that exposure to chromium can lead to both DNA protein cross-linking (Mattagajasingh and Misra 1996) and DNA-DNA cross-linking (Xu et al. 1996). All of these effects of chromium treatment can lead to mutations in cellular genes and eventually results in cellular transformation.

Table 2 also shows that the potential of $\mathrm{K}_{2} \mathrm{Cr}_{2} \mathrm{O}_{7}$ induced chromosomal aberrations was greatly reduced in groups treated i.p. with thiola $50 \mathrm{mg} \mathrm{kg}^{-1}$ b.wt. $2 \mathrm{~h}$ prior to the administration of the metal. Such decrease was found to be statistically significant compared with the respective groups treated with $\mathrm{K}_{2} \mathrm{Cr}_{2} \mathrm{O}_{7}$ alone. A significant decrease of the structural chromosomal aberrations and a reduction of the incidence of $\mathrm{C}$-mitosis have been obtained. The same protective effect of thiola was reported against the genotoxicity induced by benzo (a) pyrene in human embryonic lung fibroblasts of the cell line I CP-23 and in $\mathrm{C}_{56 \mathrm{~B} 1 / 6}$ mouse bone-marrow (Galdean et al. 1986). Moreover a protective effect of thiola was also noted in human peripheral blood cells treated with different mutagens (Dallapiccola et al. 1985). The results illustrated in Tables 1 and 2 concerning the protective role of thiola indicate that the induction of chromosomal aberrations and SCE's by $\mathrm{K}_{2} \mathrm{Cr}_{2} \mathrm{O}_{7}$ is partially based on different mechanisms.

The induction of chromosomal aberrations in mouse spermatocytes after single i.p. treatment with different doses of $\mathrm{K}_{2} \mathrm{Cr}_{2} \mathrm{O}_{7}\left(3,6,12,24 \mathrm{mg} \mathrm{kg}^{-1}\right.$ b.wt.) was also studied (Table 3). All the tested concentrations had induced a significant increase in the percentage of chromosomal aberrations in mouse spermatocytes with a dose-related relationship. Such percentage reached $6.20 \pm 0.89$ and $12.60 \pm 0.45$ after treatment with the lowest and the highest tested doses respectively compared with $3.60 \pm 0.24$ for the control. After treatment with different doses of $\mathrm{K}_{2} \mathrm{Cr}_{2} \mathrm{O}_{7}$ chromosomal aberrations (Fig. 1g-i) were observed in mouse spermatocytes. Univalent formation was highly increased (X-Y and autosomal univalents). However, X-Y univalents were much more frequent. Breaks, fragments and translocations were also observed. The results also show that thiola significantly reduced the incidence of chromosomal abnormalities induced by $\mathrm{K}_{2} \mathrm{Cr}_{2} \mathrm{O}_{7}$ in mouse spermatocytes. The mean percentage of aberrant metaphases reached $7.20 \pm 0.37$ after treatment with the highest tested dose of $\mathrm{K}_{2} \mathrm{Cr}_{2} \mathrm{O}_{7}$ and $50 \mathrm{mg} \mathrm{kg}^{-1}$ b.wt. thiola compared with $12.60 \pm 0.45$ for those treated with the same dose of $\mathrm{K}_{2} \mathrm{Cr}_{2} \mathrm{O}_{7}$ alone.

The above results suggest that the environmental contamination by potassium dichromate may bring about serious problems to human health including genetic hazards. The results also clearly illustrate the protective role of thiola which succeed for minimizing the incidence of chromosomal aberrations induced by $\mathrm{K}_{2} \mathrm{Cr}_{2} \mathrm{O}_{7}$ in both somatic and germ cells of male mice.

\section{References}

Aiyar, J., Borges, K. M., Floyd, R. A. and Wetterhahn, K. E. 1989. Role of chromium (V), glutathionethiol radical, and hydroxyl radical intermediates in chromium (VI)-induced DNA damage. Toxicol. Environ. Chem. 22: 135-145.

Alain, B., Occhipinti, P., Bartcai, E. and Orsiere, T. 1997. Genotoxic effects of potassium dichromate in cultured human lymphocytes. Med. Sci. Res. 24: 797-799.

Anghileri, L. J. 1973. Calcium metabolism in tumors. Its relationship with chromium complex accumulation. Oncology 27: 30-44.

Benjamin, S. and Stephen, J. 1996. Mitoclastic and clastogenic effects of aspirin on mouse bone-marrow cells in vivo. 
Cytologia 61: 27-32.

Bianchi, V., Celotti, L., Lanfranchi, G., Majone, F., Marin, G., Montaldi, A., Sponza, G., Tamino, G., Venier, P., Zantedeschi, A. and Levis, A. G. 1983. Genetic effects of chromium compounds. Mut. Res. 117: 279-300.

Biedermann, K. A. and Landolph. J. R. 1990. Role of valence state and solubility of chromium compounds on induction of cytotoxicity, mutagenesis, and anchorage independence in diploid human fibroblasts. Cancer Res. 50: 7835-7842.

Bonatti, S., Meini, M. and Abbondandolo, A. 1976. Genetic effects of potassium dichromate. Mut. Res. 38: $147-150$.

Carlisle, D. L., Pritchard, D. E., Singh, J., Owens, B. M., Blankenship, L. J., Orenstein, J. M. and Patierno, S. R. 2000. Apoptosis and P53 induction in human lung fibroblasts exposed to chromium (VI): effect of ascorbate and tocopherol. Toxicol Sci. 55: 60-81.

Casadevall, M., Fresco, P. and Kortenkamp, A. 1999. Chromium (VI). Mediated DNA damage: Oxidative pathways resulting in the formation of DNA breaks abasic sites. Chemd. Biol. Interact. 123: 117-132.

Dallapiccola, B., Porfirio, B., Mokini, V., Alimena, G., Isacchi, G. and Gandini, E. 1985. Effect of oxidants and antioxidants on chromosomal breakage in Fanconi anemia lymphocytes. Hum. Genet. 69: 62-65.

Evans, E. P., Breckon, G. and Ford, C. E. 1964. An air drying method for meiotic preparation from mammalian testes. Cytogenetics 3: 289-294.

Ezzat, I., El-Demerdash, S., Khorshid, A., Abu-Zeid, M., Aboul-Enein, M. and El-Merzabani, M. 1982. Radiation protection of thiola in mice: II-Effect on hematopoietic system and life-span after total body irradiation. J. Egypt. Natl. Cancer Inst. 1: 77-85.

Galdean, D., Petrasincu, D., Alangiu, P., Ibric, S. and Voiculetz, N. 1986. The protective effect of thiola against the genotoxicity action of benzo (a) pyrene. Experientia 42: 572-574.

Goto, K., Maeda, S., Kano, Y. and Sugiyama, T. 1978. Factors involved in differential Giemsa staining of sister chromatids. Chromosoma 66: 351-359.

IARC. 1990. IARC Monographs on the Evaluation of Carcinogenic Risks to Humans. Vol. 49. Chromium. Nickel and Welding. World Health Organization, Lyon. pp. 115-256.

Itoh, S. and Shimada, H. 1998. Bone-marrow and liver mutagenesis in Laczz transgenic mice treated with hexavalent chromium Mut. Res. 412: 63-67.

Knudsen, I. 1980. The mammalian spot test and its use for the testing of potential carcinogenicity of welding fume particles and hexavalent chromium. Acta pharmacol. Toxicol. 47: 66-70.

Kohlpoth, M., Rusche, B. and Nusse, M. 1999. Flow cytometric measurement of micronuclei induced in a permanent fish cell line as a possible screening test for the genotoxicity of industrial waste waters. Mutagenesis 14: 397-402.

Leonard, A. and Lauwerys, R. R. 1980. Carcinogenicity and mutagenicity of chromium. Mut. Res. 76: 227-239.

Levis, A. G., Bianchi, V., Tamino, G. and Pegoraro, B. 1978a. Cytotoxic effects of hexavalent and trivalent chromium compounds on mammalian cells in vitro. Br. J. Cancer 37: 386-396.

-, Buttignol, M., Bianchi, V. and Sponza, G. 1978b. Effect of potassium dichromate on nucleic acid and protein syntheses and on precursor uptake in BHK fibroblasts. Cancer Res. 38: 110-116.

Madrigal-Bujaidar, E., Diaz Barriga, S., Cassani, M., Molina, D. and Ponce, G. 1998. In vivo and in vitro induction of sister chromatid exchanges by nordihydroguaiaretic acid. Mut. Res. 412: 139-144.

Majone. F. 1977. Effects of potassium dichromate on mitosis of cultured mammalian cells. Caryologia 30: 468-481.

- and Levis, A. G. 1979. Chromosomal aberrations and sister chromatid exchanges in Chinese hamster cells treated in vitro with hexavalent chromium compounds. Mut. Res. 67: 231-238.

Mattagajasingh, S. and Misra, H. P. 1996. Mechanisms of the Chromium (VI)-induced DNA-protein cross-links and their characterization in cultured intact human cells. J. Biol. Chem. 271: 33550-33560.

Mazia, D. 1954: The particulate organization of chromosome, Proc. Natl. Acad. Sci. (USA) 40: 521-527.

Nakamuro, K., Yoshikawa, K., Sayato, Y. and Kurata, H. 1978. Comparative studies of chromosomal aberrations and mutagenicity of trivalent and hexavalent chromium. Mut. Res. 58: 175-181.

Newbold, R. F., Amos, J. and Connell, J. R. 1979. The cytotoxic, mutagenic and clastogenic effects of chromium containing compounds on mammalian cells in culture. Mut. Res. 67: 55-63.

Ohno, H., Hanaoka, F. and Yamada, M. 1982. Inducibility of sister chromatid exchanges by heavy metal ions. Mut. Res. 104: 141-145.

Russo, A., Dorigo, E., Stocco, A. and Majone, F. 1993. Persistence of chromosomal lesions induced in mouse bone-marrow cells by mitomycin C, as evaluated by SCE analysis. Mut. Res. 287: 275-282.

Schunck, C., Miura, K. F. and Obe, G. 1998. Thiopronin reduces the frequencies of neocarzinostatin induced chromosomal aberrations and sister chromatid exchanges in Chinese hamster ovary cells. Mut. Res. 412: 207-212.

Siegfried, K., Gottmann, E., Steinkellner, H., Fomin, A., Pickl, C., Paschke, A., Göd, R. and Kundi, M. 1998. Detection of genotoxic effects of heavy metal contaminated soils with plant bioassays. Mut. Res. 420: 37-48.

Singh, J., Pritchard, D. E., Carlisle, D. L., Mclean, J. A., Montaser, A., Orenstein, J. M. and Patierno, S. R. 1999. Internalization of carcinogenic lead chromate particles by cultured normal human lung epithelial cells: formation of intracellular lead. Inclusion bodies and induction of apoptosis. Toxicol. Appl. Pharmacol. 161: 240-248. 
Strohs, S. J. and Bagchi, D. 1995. Oxidative mechanisms in the toxicity of metal ions. Free Radic. Biol. Med. 18: 321-336.

Sugahara, T. and Srivastava, P. N. 1976. MPG (2-Mercaptopropionylglycine) A Review on Its Protective Action against Ionizing Radiations. International Atomic energy. Agency, Vienna. 77-87.

Tsuda, H. and Kato, K. 1976. Potassium dichromate induced chromosome aberrations and its control with sodium in hamster embryonic cells in vitro. Gann 67: 469.

— and - 1977. Chromosomal aberrations and morphological transformation in hamster embryonic cells treated with potassium dichromate in vitro. Mut. Res. 46: 87-94.

Uma Devi, P. and Prasanna, P. G. 1990. Radioprotective effect of combinations of WR-2721 and mercaptopropionylglycine on mouse bone-marrow chromosomes. Rad. Res. 124: 165-170.

Umeda, M. and Nishimura, M. 1979. Inducibility of chromosomal aberrations by metal compounds in cultured mammalian cells. Mut. Res. 67: 221-229.

Xu, J., Bubley, G. J., Detrick, B., Blankenship, L. J. and Patierno, S. R. 1996. Chromium (VI) treatment of normal human lung cells results in guanine-specific DNA polymerase arrest, DNA-DNA cross links, and S-phase blockage of cell cycle. Carcinogenesis 17: 1511-1517.

Yosida, T. H. and Amano, K. 1965. Autosomal polymorphism in laboratory bred and wild Norway rats, Rattus norvegicus found in Misima. Chromosoma. 16: 658-667. 